\title{
The use of amisulpride in schizophrenic patients with resistant symptomatology
}

\author{
Dimitrios Kalfas", Sophia Markou, Apostolos Gkletsos, Maria Parga, Theodoros Karras \\ From $1^{\text {st }}$ International Congress on Neurobiology and Clinical Psychopharmacology and European \\ Psychiatric Association Conference on Treatment Guidance \\ Thessaloniki, Greece. 19-22 November 2009
}

\section{Background}

The purpose of this study was to evaluate the use of the pharmaceutical drug Amisulpride (Solian) in schizophrenic patients with resistant semiology

\section{Materials and methods}

The material of this study was 21 patients (17 men and 4 women) who were diagnosed with schizophrenic disorder paranoid type based on DSM-IV, and were recorded with durable symptomatology (delusions, paranoid ideas etc.) even though the continuous issuing of Amisulpride in normal doses (800-1200 mg/daily). In these patients was given Amisulpride in larger doses than the proposed (1600-2000 mg/daily). The evaluation was done with the PANSS scale

\section{Results}

After a 30 day time interval and while the continuous issuing of Amisulpride in larger doses was observed considerably reprocess of the resistant symptoms, fact that recorded at the grade alleviation at PANSS scale

\section{Conclusions}

Is concluding that the continuous issuing of Amisulpride in larger doses than the normal ones help considerably in obliteration of the durable symptoms of schizophrenia.

Submit your next manuscript to BioMed Central and take full advantage of:

- Convenient online submission

- Thorough peer review

- No space constraints or color figure charges

- Immediate publication on acceptance

- Inclusion in PubMed, CAS, Scopus and Google Scholar

- Research which is freely available for redistribution

Submit your manuscript at www.biomedcentral.com/submit

\section{( Biomed Central}

